\title{
IDENTIFICATION OF FUNCTIONAL TYPES OF RURAL COMMUNES IN POLAND
}

\author{
Agnieszka Kozera, $\mathrm{PhD}^{1}$; Romana Głowicka-Wołoszyn, $\mathrm{PhD}^{2}$
}

Faculty of Economics and Social Sciences, Poznań University of Life Sciences

\begin{abstract}
The aim of the research was to identify the functional structure of rural communes in Poland. The functional types were further characterized and spatially delimited. The research drew on 2015 data from the Central Statistical Office database, Local Data Bank and statistical yearbooks: 'Voivodship, subregions, poviats and communes'. Identification of functional types of rural communes in Poland employed a structural approach that classifies an administrative unit according to its prevalent social and economic functions. The optimal number of typological classes was first determined from the dendrogram produced by the Ward's method. Then, the $k$-means method was employed to perform the actual classification.
\end{abstract}

Keywords: rural communes, functional types of rural communes, Ward's method, $k$-means method JEL codes: $\mathrm{R} 1, \mathrm{C} 38$

\section{INTRODUCTION}

Rural development issues received much attention after Poland's entry into EU (Bański, 2014a; Hadyński, 2015; Heffner and Klemens, 2016; Kozera 2017). Of particular importance in this respect was the research conducted by the Institute of Rural and Agricultural Development (Monitoring Rural Development 2016), and by the Foundation for the Development of Polish Agriculture (Wilkin and Nurzyńska, eds., 2016). This interest is dictated by the simple fact that rural areas cover over $90 \%$ of the country's total area and are home to over $30 \%$ of the total population ${ }^{3}$.

Communes, as the lower tier of local administrative units, can be divided into three administrative types: urban, rural or mixed urban-rural. In 2015 there were 2,478 communes in Poland, of which roughly $63 \%$ were rural and $13 \%$ urban $^{4}$. The basic functions of rural communes were still related to agriculture, though driven by social and economic changes many rural communes were in the process of transformation from typically agricultural to multifunctional, mainly residential and service oriented (Kozera and Wysocki, 2015). This functional mix is the fundamental benchmark for rural communes typology viewed as a prediction tool for their growth potential. Identification of their functional structure is then not only of a cognitive merit, but also has applicative values. As Śleszyński points out (2012), it allows for more effective management through the use of rural areas

${ }^{1}$ Corresponding author: Wojska Polskiego 28,60-637 Poznań, Poland, akozera@up.poznan.pl, +4861 8487111

${ }^{2}$ Corresponding author: Wojska Polskiego 28, 60-637 Poznań, Poland, roma@up.poznan.pl, +4861 8466185

${ }^{3}$ Local Data Bank webpage https://bdl.stat.gov.pl/BDL/dane/podgrup/temat [Accessed 05.05.2017].

${ }^{4}$ Ibidem. 
specific resources and assets, which in turn determine the character of its social and economic development. It is the reason why modern principles of regional development policy-making, that inform both EU and national policy documents, place such emphasis on research of territorial units in terms of their natural and socio-economic specificity. A synthetic classification of their individual characteristics may be of paramount importance for programming appropriate policy measures (Bański, 2014b). The classification of rural areas in Poland in terms of the level and dynamics of their socio-economic development is covered by many studies, including Rosner (2007), Stanny (2013), Rosner and Stanny (2016).

The aim of the research was to identify the functional structure of rural communes in Poland. The functional types were further characterized and spatially delimited.

\section{MATERIALS AND METHODS}

The research drew on 2015 data from the Central Statistical Office database, Local Data Bank and statistical yearbooks: 'Voivodship, subregions, poviats and communes' (GUS, 2015). Identification of functional types of rural communes in Poland employed a structural approach that classifies an administrative unit according to its prevalent social and economic functions (Dijkstra and Poelman, 2008; Bański 2014b). The research was carried out in four stages:

Step 1. Selection of simple features describing functions performed by communes (functional types). The selection was motivated by the perceived merit of the features in describing residential, industrial, commercial, agricultural and tourism functions (Table 1). An initial set of draft features was subjected to statistical scrutiny for their information gain (through VIF threshold approach to collinearity) and discriminatory ability (by removing features with little variability). As a result features $x_{3}, x_{5}, x_{7}$ and $x_{8}$ were omitted from further analysis.

Step 2. Normalization of simple features - by classical standardization (Wysocki, 2010).

Step 3. Rural communes' classification by Ward's and $k$-means methods. The functional classification of rural communes was carried out using two cluster analysis methods: Ward's and $k$-means. Cluster analysis attempts to group objects into classes (clusters) in such a way that objects in the same cluster are more similar to each other than to those in other clusters. This creates a set of fairly homogeneous classes that are dissimilar between each other (Migut, 2009). In this step, the optimal number of typological classes was first determined from the dendrogram produced by the Ward's method. Then, the $k$-means method was employed to perform the actual classification.

Step 4. Identification of functional types, their characterization and spatial distribution. Interpretation of the classes created in the previous step required that relevant features for each class were properly identified. First, class means and standard deviations were calculated for each feature. As all were measured on ratio scales, pseudo-test of mean differences could be used (Wysocki, 2010):

$$
t_{c k}=\frac{\bar{x}_{c k}-\bar{x}_{k}}{s_{c k}}
$$

Like in the classical t-test, the pseudo-test t-statistics measures the distance from the $c$-th class mean $\bar{x}_{c k}$ to the overall mean $\bar{x}_{k}$ and expresses the distance in the class mean's standard error units $s_{c k}$. The variance of the class mean is given by the formula:

$$
s_{c k}^{2}=\frac{N-N_{c}}{N-1} \cdot \frac{s_{k}^{2}}{N_{c}}
$$

where:

$s_{k}^{2}-$ (total) empirical variance of the $k$-th feature;

$N_{c}-$ size of the $c$-th class;

$N$ - number of objects.

The larger the absolute value of the t-statistics the more relevant is the feature to a given class. The degree of this relevance can be categorized by the following benchmarks (Wysocki, 2010): if the absolute value exceeds 3 , the feature is considered highly relevant, if it falls between 2 and 3 - moderately relevant, and if smaller than 2 - the feature is regarded as irrelevant. The highly relevant features to a given class were taken to identify main functions performed by the class communes, and gave that class its functional name. 
Proceedings of the 2018 International Scientific Conference 'Economic Sciences for Agribusiness and Rural Economy' No 1, Warsaw, 7-8 June 2018, pp. 109-115

Table 1. Simple features describing functions performed by communes

\begin{tabular}{|c|c|}
\hline Designation & Feature name \\
\hline \multicolumn{2}{|r|}{ Residential functions } \\
\hline$x_{1}$ & Population density per $\mathrm{km}^{2}$ \\
\hline$x_{2}$ & Population change per 1,000 inhabitants (for 2013-2015) \\
\hline$x_{3}$ & Non-working age to 100 of working age population ratio \\
\hline $\mathrm{x}_{4}$ & Post-working age to 100 of pre-working age population ratio \\
\hline$x_{5}$ & Post-working age to 100 of working age population ratio \\
\hline$x_{6}$ & Residential in urbanized area $(\%)$ \\
\hline$x_{7}$ & Dwellings per 1,000 inhabitants \\
\hline \multicolumn{2}{|r|}{ Industrial/Commercial functions } \\
\hline$x_{8}$ & Urbanized area $(\%)$ \\
\hline$x_{9}$ & Industrial and mining in urbanized area $(\%)$ \\
\hline$x_{10}$ & Registered business enterprises per 10,000 inhabitants \\
\hline$x_{11}$ & Newly registered business enterprises per 10,000 inhabitants \\
\hline$x_{12}$ & Enterprises employing over 50 persons per 10,000 working age inhabitants \\
\hline$x_{13}$ & Industry workers per 100 working age inhabitants \\
\hline \multicolumn{2}{|r|}{ Agricultural functions } \\
\hline$x_{14}$ & Individual farmstead workers per 100 working age inhabitants* \\
\hline$x_{15}$ & Agricultural holdings with area of over 15 ha (\%) \\
\hline$x_{16}$ & NPK fertilizer consumption in kg per UAA ha \\
\hline$x_{17}$ & Large livestock per 100 UAA ha \\
\hline$x_{18}$ & Agricultural area $(\%)$ \\
\hline \multicolumn{2}{|r|}{ Tourism functions } \\
\hline$x_{19}$ & Accommodations per 1,000 inhabitants \\
\hline$x_{20}$ & Land under the waters area $(\%)$ \\
\hline$x_{21}$ & Forest area $(\%)$ \\
\hline
\end{tabular}

* Own estimates taking into account persons working on individual farmsteads (on average two persons per farmstead).

Source: own elaboration.

\section{RESULTS}

Functional classification of rural communes in Poland produced five typological classes, whose spatial distribution is presented in Figure 1. Table 2 shows class means of simple features together with designations of feature-to-class relevance levels (highly positive or highly negative) computed from the criteria of the pseudo-test of mean differences.

Rural communes perform primarily the basic function of rural areas, that is agriculture. In 2015 nearly half of all rural communes were of two purely 
Proceedings of the 2018 International Scientific Conference 'Economic Sciences for Agribusiness and Rural Economy' No 1, Warsaw, 7-8 June 2018, pp. 109-115

Table 2. Class mean values of simple features and relevance of features across typological classes of rural communes in Poland

\begin{tabular}{|c|c|c|c|c|c|c|}
\hline \multirow[b]{3}{*}{ Specification } & \multicolumn{5}{|c|}{ Typological class } & \multirow[b]{3}{*}{ Overall } \\
\hline & I & II & III & IV & $\mathrm{V}$ & \\
\hline & $\begin{array}{l}\text { agricultural } \\
\text { intensive }\end{array}$ & $\begin{array}{l}\text { multifunc- } \\
\text { tional }\end{array}$ & $\begin{array}{l}\text { agricultural } \\
\text { exten- } \\
\text { sive with } \\
\text { growing } \\
\text { residential }\end{array}$ & $\begin{array}{l}\text { agricultural } \\
\text { extensive }\end{array}$ & $\begin{array}{r}\text { residential/ } \\
\text { /industrial }\end{array}$ & \\
\hline Percentage of communes (\%) & 26.0 & 18.0 & 27.3 & 23.5 & 5.2 & 100 \\
\hline \multicolumn{7}{|c|}{ Residential functions } \\
\hline Population density per $\mathrm{km}^{2}$ & $43.0^{N}$ & 63.5 & $69.1^{P}$ & $42.7^{N}$ & $242.0^{P}$ & 51.6 \\
\hline $\begin{array}{l}\text { Population change per 1,000 inhabitants (for } \\
\text { 2013-2015) }\end{array}$ & $-8.4^{N}$ & $15.5^{P}$ & $1.7^{P}$ & $-18.5^{N}$ & $28.5^{P}$ & -3.6 \\
\hline $\begin{array}{l}\text { Post-working age to } 100 \text { of pre-working age } \\
\text { population ratio }\end{array}$ & $86.6^{N}$ & $75.3^{N}$ & $87.3^{N}$ & $118.7^{P}$ & $79.6^{N}$ & 90.1 \\
\hline Residential in urbanized area $(\%)$ & $8.1^{N}$ & $17.5^{P}$ & 9.4 & $1.7^{N}$ & $37.9^{P}$ & 8.7 \\
\hline \multicolumn{7}{|c|}{ Industrial/Commercial functions } \\
\hline $\begin{array}{l}\text { Registered business enterprises } \\
\text { per } 10,000 \text { inhabitants }\end{array}$ & $599.8^{N}$ & $871.1^{P}$ & $641.6^{N}$ & $512.8^{N}$ & $1078.2^{P}$ & 638.2 \\
\hline $\begin{array}{l}\text { Newly registered business enterprises } \\
\text { per } 10,000 \text { inhabitants }\end{array}$ & $56.7^{N}$ & $84.9^{P}$ & 62.8 & $44.2^{N}$ & $87.0^{P}$ & 60.0 \\
\hline $\begin{array}{l}\text { Enterprises employing over } 50 \text { persons } \\
\text { per } 10,000 \text { working age inhabitants }\end{array}$ & $3.2^{N}$ & $7.0^{P}$ & $2.9^{N}$ & $2.7^{N}$ & $8.5^{P}$ & 3.8 \\
\hline Industry workers per 100 working age inhabitants & $1.5^{N}$ & $6.9^{P}$ & $2.8^{N}$ & $0.0^{N}$ & $8.6^{P}$ & 2.5 \\
\hline Industrial and mining in urbanized area (\%) & $2.0^{N}$ & $4.2^{P}$ & $2.0^{N}$ & $0.7^{N}$ & $3.7^{P}$ & 2.0 \\
\hline \multicolumn{7}{|c|}{ Agricultural functions } \\
\hline $\begin{array}{l}\text { Individual farmstead workers per } 100 \text { working } \\
\text { age inhabitants }\end{array}$ & $45.9^{P}$ & $24.5^{N}$ & $50.6^{P}$ & $65.2^{P}$ & $14.8^{N}$ & 44.3 \\
\hline Agricultural holdings with area of over 15 ha (\%) & $23.5^{P}$ & 11.7 & $2.0^{N}$ & $7.5^{N}$ & $1.7^{N}$ & 9.1 \\
\hline NPK fertilizer consumption in kg per UAA ha & $152.3^{P}$ & $105.8^{P}$ & $46.7^{N}$ & 104.3 & $75.3^{N}$ & 101.0 \\
\hline Large livestock per 100 UAA ha & $67.8^{P}$ & 46.3 & $30.5^{N}$ & $34.3^{N}$ & $23.6^{N}$ & 42.9 \\
\hline Agricultural area (\%) & $75.6^{P}$ & $56.7^{N}$ & $60.6^{N}$ & $77.2^{P}$ & $64.7^{N}$ & 69.3 \\
\hline \multicolumn{7}{|c|}{ Tourism functions } \\
\hline Land under the waters area $(\%)$ & 0.5 & $1.4^{P}$ & $0.7^{N}$ & $0.3^{N}$ & 0.6 & 0.6 \\
\hline Forest area (\%) & $17.7^{N}$ & $32.7^{P}$ & $33.2^{P}$ & $18.9^{N}$ & $17.8^{N}$ & 23.2 \\
\hline Accommodations per 1,000 inhabitants & $0.0^{N}$ & $6.5^{P}$ & $2.9^{N}$ & $0.0^{N}$ & 3.4 & 0.0 \\
\hline
\end{tabular}

Designation of feature-to-class relevance: $P$ - highly relevant and positive, $N$ - highly relevant and negative Source: own elaboration based on Central Statistical Office data. 


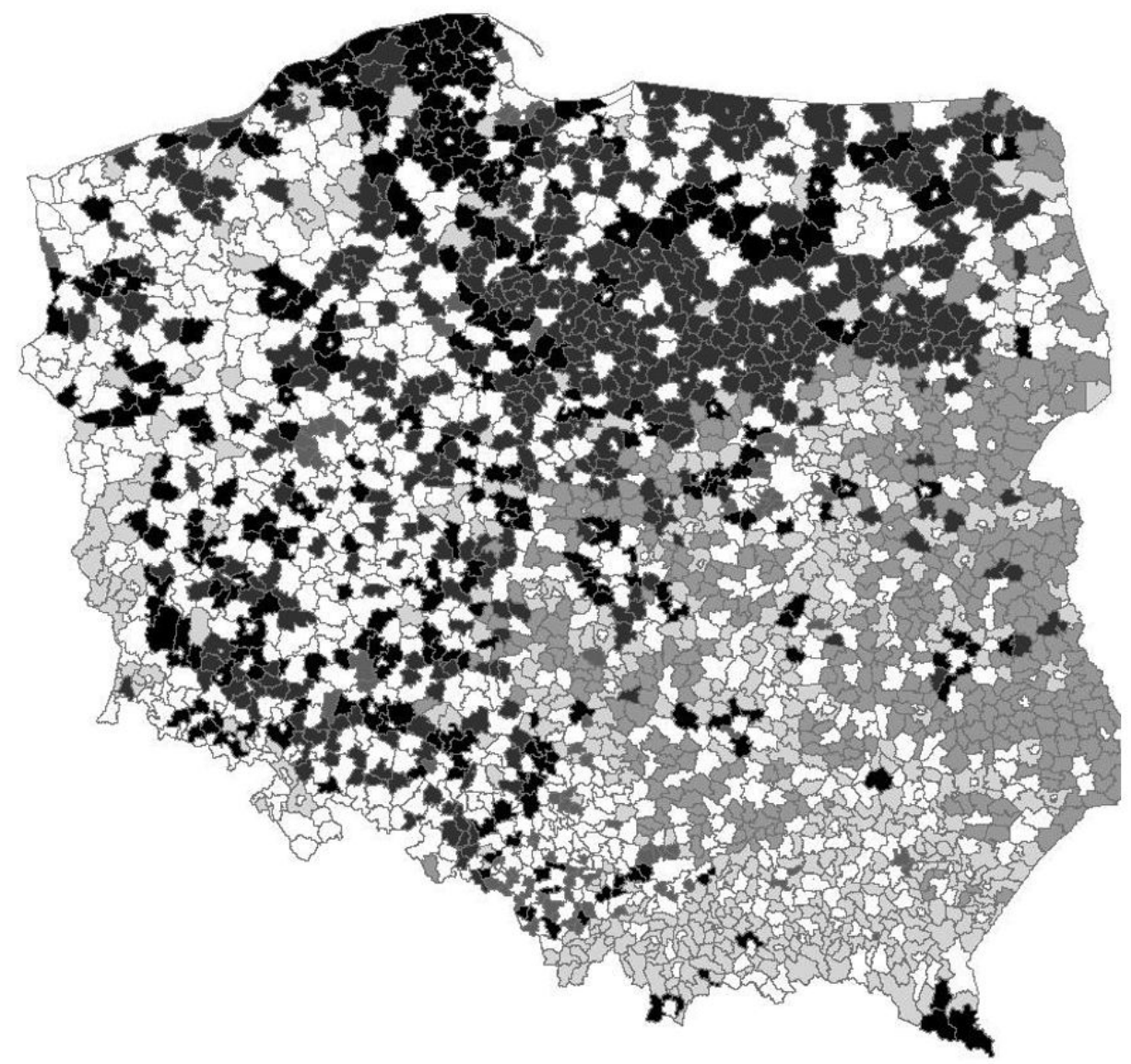

Functional types of rural communes:

Figure 1. Spatial delimitation of functional types of rural communes in Poland in 2015

multifunctional agricultural intensive residential/ industrial agricultural extensive agricultural extensive with growing residential urban and ruralurban communes (communes omitted in the study)

Source: own elaboration based on Central Statistical Office data.

agricultural types: intensive (Class I) $-26 \%$, and extensive (Class IV) - 23.5\% (Table 1). These communes were located mainly in the north-eastern part of the country (intensive agricultural type) and in the mid-eastern (extensive agricultural type) (Fig. 1). Their most relevant features were related to agricultural activity (Table 2), and for class IV characterized by high number of individual farmstead workers (65.2), high share of agricultural area (72.2\%), low percentage of over 15 ha agricultural holdings (7.5\%), and small number of large livestock (34.3). In this class processes of depopulation and aging could be observed. Relevant features of this class were high negative population change $(-18.5)$ and high post-working age/pre-working age population ration (118.7) - Table 2.
On the other hand, the communes forming Class I (intensive agricultural) were characterized by the large percentage of over 15 ha agricultural holdings (23.5\%), high NPK consumption (152.3) and high number of large livestock (67.8). Rural communes of this class were also affected by depopulation, but to a much lesser extent than those of Class IV. Class III communes (agricultural with growing residential functions) constituted over one fourth of all rural communes $(27.3 \%)$ and were located mainly in the southeastern part of the country (Fig. 1). Relevant and positive features of this class were high population density (69.1) and population growth $(+1.7)$, but more than half of the working age population still worked on individual farms. Interestingly, these communes had also high share of forest area (33.2\%) (Table 2). 
Nearly every fifth rural commune (18.0\%) belonged to the second class of multifunctional type. These communes were located mainly in the northern and western part of the country (Fig. 1). Relevant features of this class were low number of individual farmstead workers (24.5), positive and large population change (15.5) and development of industrial and commercial functions: high number of registered enterprises (871.1), of large enterprises (7.0), and industrial workers (6.9). In these communes, in particular in the northern part of the country, the tourist function was also developing, as evidenced by high number of accommodations (6.5) - Table 2.

The residential /industrial communes (Class V) represented only $5.2 \%$ of all rural communes. They had lost their typically rural, agricultural character. Residential, industrial and service-oriented functions were performed by rural communes located in the vicinity of large urban centers such as Warszawa, Poznań, Katowice and Kraków. They were characterized by relevant features related to suburbanization processes: very large population change (28.5) and density (242), high number of registered enterprises $(1,078)$, and high number industry workers $(8.6)$ (Fig. 1, Table 2).

\section{CONCLUSIONS}

The idea of multifunctional rural growth model assumes a gradual shift from exclusive agriculture-based development towards diversification with non-agricultural functions, such as residential, commercial, transportation, service and tourism. Such model is to promote entrepreneurship and put the local economy on a more robust and sustainable development path and, as a result, improve the quality of life of the inhabitants.

Empirical research showed that agriculture remains the basic function of rural communes in Poland. Half of the communes still perform mainly agricultural functions, characteristic of either extensive or intensive agriculture. In $27 \%$, alongside extensive agriculture residential functions have been developing. Only $5 \%$ of rural communes have lost completely its agricultural character and perform typically residential or industrial functions, while
$18 \%$ are distinguished by multifunctional development.

One of the most important results of the research is the confirmation of regional diversification in the scope of performed functions, especially between rural communes located in the eastern and western part of Poland. In eastern rural communes dominates the mono-functional character of local economy, with intensive agricultural functions in the north-east and extensive ones in the mid-eastern part of the country. Extensive agricultural model with developing residential functions predominates in the south-eastern regions, and multifunctional development is observed mainly in the western part of Poland.

\section{REFERENCES}

1. Bański, J. (2014a). Perspektywy rozwoju polskiej wsi - wybrane zagadnienia [Prospects for the development of the rural areas in Poland - selected issues]. Wieś i Rolnictwo, 4 (165), pp. 13-25.

2. Bański, J. (2014b). Współczesne typologie obszarów wiejskich w Polsce - przegląd podejść metodologicznych [Contemporary typologies of rural areas in Poland - a review of methodological approaches]. Przegląd Geograficzny, 86 (4), pp. 441-470.

3. Dijkstra, L., Poelman, H. (2008). Remote Rural Regions, How proximity to a city influences the performance of rural regions. Regional Focus, 1, DG Regio, European Commission.

4. GUS (2015). Województwo, podregiony, powiaty i gminy [Voivodship, subregions, poviats and communes]. Główny Urząd Statystyczny, Warszawa. Retrieved from: http://stat.gov.pl/statystyka-regionalna [Accessed 20.05.2017].

5. Hadyński, J. (2015). Regionalna konkurencyjność obszarów wiejskich [Regional competitiveness of rural areas]. Wydawnictwo Uniwersytetu Przyrodniczego w Poznaniu, Poznań.

6. Heffner, K., Klemens, B. (red.) (2016). Obszary wiejskie: wiejska przestrzeń i ludność, aktywność społeczna i przedsiębiorczość [Rural areas - countryside expanse and population, social activity and enterpreneurship]. Komitet Przestrzennego Zagospodarowania Kraju PAN, Warszawa.

7. Kozera, A. (2017). Problem zadłużenia gmin wiejskich na przykładzie województwa wielkopolskiego (The problem of indebtedness of rural communes on the 
example of the Wielkopolskie voivodship). Wieś i Rolnictwo 1 (174), pp. 75-97.

8. Kozera, A., Wysocki, F. (2015). Typ funkcjonalny a samodzielność finansowa gmin wiejskich województwa wielkopolskiego [The functional type and financial self-sufficiency of rural communes of the Wielkopolska province]. Roczniki Naukowe Stowarzyszenia Ekonomistów Rolnictwa i Agrobiznesu, 17 (6), pp. 133-139.

9. Migut, G. (2009). Czy stosowanie metod data mining może przynosić korzyści w badaniach naukowych? StatSoft Polska Sp. z o.o. Retrieved from: https://.statsoft.pl/Czytelnia/?kc=BVLG [Accessed 20.05.2017].

10. Rosner A. (ed.) (2007). Zróżnicowanie poziomu rozwoju społeczno-gospodarczego obszarów wiejskich a zróżnicowanie dynamiki przemian [Variations in the Level of Socio-Economic Development of Rural Areas in Poland in Comparison to the Variations in Transformation Dynamics]. IRWiR PAN, Warszawa.

11. Rosner, A., Stanny, M. (2016). Monitoring rozwoju obszarów wiejskich - Etap II [Monitoring rural develop- ment - Stage II]. Fundacja Europejski Fundusz Rozwoju Wsi Polskiej, IRWiR PAN, Warszawa.

12. Stanny, M. (2013). Przestrzenne zróżnicowanie rozwoju obszarów wiejskich w Polsce [Spatial diversification of rural area development in Poland]. IRWiR PAN, Warszawa.

13. Śleszyński, P. (2012). Klasyfikacja gmin województwa mazowieckiego [Classification of gminas in Poland's Mazowieckie voivodship]. Przegląd Geograficzny, 84 (4), pp. 559-576.

14. Wilkin, J., Nurzyńska, I. (eds.) (2016). Polska wieś 2016. Raport o stanie wsi [Rural Poland 2016. Report on the State of Rural Areas]. Fundacja na Rzecz Rozwoju Polskiego Rolnictwa. Wydawnictwo Naukowe Scholar, Warszawa.

15. Wysocki, F. (2010). Metody taksonomiczne w rozpoznawaniu typów ekonomicznych rolnictwa i obszarów wiejskich [The methods of taxonomy for recognition of economic types in agriculture and rural areas]. Wydawnictwo Uniwersytetu Przyrodniczego w Poznaniu, Poznań. 